\title{
Acoustic voice parameters in hearing-impaired, school-aged children. Research study outcomes
}

Agata Szkiełkowska ${ }^{1}$, Karol Myszel ${ }^{2 *}$

${ }^{1}$ Audiology and Phoniatrics Clinic, Institute of Physiology and Pathology of Hearing, Warsaw, Poland.

${ }^{2}$ Center of Hearing and Speech, Kajetany, Poland.

*Corresponding Author: Karol Myszel, 2Center of Hearing and Speech, Kajetany, Poland.

Received date: May 06, 2021: Accepted date: June 26, 2021: Published date: July 26, 2021

Citation: Szkiełkowska A., Myszel K., (2021). Acoustic voice parameters in hearing-impaired, school-aged children. Research study outcomes; $J$. of Clinical Otorhi. 3(3). DOI: 10.31579/2692-9562/034

Copyright: (C) 2021, Karol Myszel. This is an open access article distributed under the Creative Commons Attribution License, which permits unrestricted use, distribution, and reproduction in any medium, provided the original work is properly cited.

\begin{abstract}
Aim/Background: Individuals deprived of full hearing ability suffer from many problems in their social, professional, and personal lives. Prolonged hearing deprivation, particularly in children, results in many consequences including loss of control of one's voice. Impaired hearing control of the voice leads to dysphonia of different degrees. The aim of this study was to analyse acoustic voice parameters in hearing-impaired, school-aged children (7-12 years) and the influence of treatment type on voice quality.

Material and method: The subjects in this study were a group of 83 Polish school children, aged 7-12 years. ENT and phoniatric examination were performed on each subject prior to inclusion. Acoustic voice analysis was performed for each individual. The linguistic material was a prolonged [a] vowel. The acoustic analysis was performed with a digital spectrograph KAY 4300B for multidimensional voice analysis MDVP (Multi-Dimensional Voice Profile). The criterion to include patients in the study group was a profound prelingual, sensorineural hypoacusis. Within the study group, four subgroups were categorised according to the use of hearing devices: 20 children without any type of hearing device (HL), 20 children with hearing aids (HA), and 20 children with cochlear implants (CI). The children using hearing aids and cochlear implants were included in the study 6 months after the hearing rehabilitation was implemented. The control group $(\mathrm{NH})$ consisted of 23 normal-hearing children, in the same age group, without any co-existing voice disorders. The statistical level of significance $p<0.05$ was used.
\end{abstract}

Results: The selected, clinically significant voice parameters were analysed for the groups of children in the study.

Keywords: Acoustic voice; school-aged children; dysphonia

Fundamental frequency Fo is an arithmetical average of fundamental frequency in the analysed sample, excluding voice breaks. In the group of hearing-impaired children HL, the highest value of average fundamental frequency was observed (F0). The analysis performed 6 months after hearing aid use began, showed a slight decrease in the average value of F0 and a significant decrease in the value after 6 months of cochlear implant use. These changes were statistically significant with $\mathrm{p}<0.024$ (Table 1 ).

\begin{tabular}{|c|c|c|c|c|c|}
\hline \multicolumn{7}{|c|}{ Fundamental Frequency: F0 } & \\
\hline $\begin{array}{c}\text { Group of patients } \\
\text { with: }\end{array}$ & $\begin{array}{c}\text { No of } \\
\text { patients }\end{array}$ & Average $[\mathrm{Hz}]$ & $\begin{array}{c}\text { Standard deviation } \\
{[\mathrm{Hz}]}\end{array}$ & $\begin{array}{c}\text { Median } \\
{[\mathrm{Hz}]}\end{array}$ & $\begin{array}{c}\text { Geometrical average } \\
{[\mathrm{Hz}]}\end{array}$ \\
\hline Normal hearing & 23 & 217,38 & 16,86 & 217,62 & 216,77 \\
\hline Hearing aids & 20 & 281,73 & 90,2 & 260,68 & 270,55 \\
\hline Cochlear implants & 20 & 268,49 & 66,13 & 259,04 & 261,78 \\
\hline $\begin{array}{c}\text { Hearing } \\
\text { impairment }\end{array}$ & 20 & 289,49 & 91,16 & 264,47 & 277,52 \\
\hline significance \\
$\mathrm{p}<0,024$ \\
\hline Total & 83 & 262,58 & 75,82 & 242,96 & 253,97 \\
\hline
\end{tabular}

Table 1: Average Value of Fundamental Frequency (FO) 
Individuals who used hearing aids presented with a decrease of F0 after 6 months of use, whilst a much greater decrease of F0 was observed in individuals using cochlear implants.

Highest fundamental frequency Fhi describes the highest of all voice frequencies in a sample. We found that values differed significantly between subgroups
( $p<0.0002$ ). In hearing-impaired children HL, the highest average value of Fhi was observed. A significant decrease was noted when compared with children fit with hearing aids, whilst a significant increase was noted when compared with children fit with cochlear implants. (Table 2)

\begin{tabular}{|c|c|c|c|c|c|}
\hline \multicolumn{7}{|c|}{ Highest Fundamental Frequency: Fhi } & \\
\hline $\begin{array}{c}\text { Group of patients } \\
\text { with: }\end{array}$ & $\begin{array}{c}\text { No of } \\
\text { patients }\end{array}$ & Average $[\mathrm{Hz}]$ & $\begin{array}{c}\text { Standard deviation } \\
{[\mathrm{Hz}]}\end{array}$ & $\begin{array}{c}\text { Median } \\
{[\mathrm{Hz}]}\end{array}$ & $\begin{array}{c}\text { Geometrical average } \\
{[\mathrm{Hz}]}\end{array}$ \\
\hline Normal hearing & 23 & 250,21 & 24,89 & 249,81 & 249,02 \\
\hline Hearing aids & 20 & 328,19 & 93,66 & 298,49 & 317,27 \\
\hline $\begin{array}{c}\text { Cochlear } \\
\text { implants }\end{array}$ & 20 & 376,18 & 126,52 & 350,69 & 358,81 \\
\hline $\begin{array}{c}\text { Hearing } \\
\text { impairment }\end{array}$ & 20 & 344,88 & 126,78 & 319,01 & 325,25 \\
\hline significance \\
$\mathrm{p}<0,0002$ \\
\\
\hline
\end{tabular}

Table 2: Average Value of Highest Fundamental Frequency (Fhi)

\section{Flo Lowest fundamental frequency Flo}

We observed no significant difference in the measurement of Flo between the subgroups.

\section{Frequency of FO modulation - Fftr (rate of incidents and} tremor frequency)

In the analysed samples, F0 modulating frequencies occurred (tremor frequencies). The statistical analysis did not show significant changes of values in respective groups.
Fundamental frequency variability vFO describes short- and long-term changes in fundamental frequency in a sample, excluding voice breaks. The examination showed an increased $\mathrm{vFO}$ in children within all groups versus the control group. The significance index was $p<0.002$, which means that the differences amongst the examined groups were statistically significant. The values observed are shown in Table 3. The vF0 parameter measured 6 months after hearing aid and cochlear implant fits did not present with significant changes.

\begin{tabular}{|c|c|c|c|c|c|}
\hline \multicolumn{5}{|c|}{ Fundamental Frequency Variability: vF0 } & \multirow{7}{*}{$\begin{array}{c}\text { Statistical } \\
\text { significance } \\
\text { p }<0,002\end{array}$} \\
\hline $\begin{array}{c}\text { Group of patients } \\
\text { with: }\end{array}$ & $\begin{array}{c}\text { No of } \\
\text { patients }\end{array}$ & Average $[\%]$ & Standard deviation $[\%]$ & Median [\%] & \\
\hline Normal hearing & 23 & 5.13 & 10.88 & 2.15 & \\
\hline Hearing aids & 20 & 5.52 & 7.98 & 3.49 & \\
\hline Cochlear implants & 20 & 8.64 & 11.44 & 5.57 & \\
\hline $\begin{array}{c}\text { Hearing } \\
\text { impairment }\end{array}$ & 20 & 5.22 & 3.79 & 3.76 & \\
\hline Total: & 83 & 6.09 & 9.07 & 3.49 & \\
\hline
\end{tabular}

Table 3: Average Value of Fundamental Frequency variability ( $v F 0)$

Number of fundamental frequency periods PER (Pitch

Periods) describes the number of fundamental frequency periods in an analysed voice sample. Our results showed a significant decrease of PER in hearing-impaired children versus the control group. The differences were statistically significant (Table 4). In the HA group, an improvement of the parameter was observed, whilst in the CI group, the improvement occurred much faster.

\begin{tabular}{|c|c|c|c|c|c|}
\hline \multicolumn{7}{|c|}{ Number of Fundamental Frequency Periods (pitch periods): per } \\
\hline $\begin{array}{c}\text { Group of patients } \\
\text { with: }\end{array}$ & $\begin{array}{c}\text { No of } \\
\text { patients }\end{array}$ & Average & Standard deviation & Median & Geometrical average \\
\hline Normal hearing & 23 & 1363.96 & 503.33 & 1274 & 1266,58 \\
\hline Hearing aids & 20 & 968.05 & 578.96 & 874 & 786,48 \\
\hline $\begin{array}{c}\text { Cochlear implants } \\
\text { Hearing } \\
\text { impairment }\end{array}$ & 20 & 1292.35 & 565.21 & 1312 & 1152,69 \\
\hline significance \\
p $<0,000005$ \\
Total:
\end{tabular}

Table 4: Average Value of Number of Fundamental Frequency Periods (PER) 
Absolute jitter (Jitter-Jita) defines absolute changes of F0 period (from period to period) in a voice sample (absolute instability). In our study, the differences of Jita and \% Jitt amongst the groups were not statistically significant.

Fundamental frequency average change quotient, RAP (Relative Average Perturbation) describes a relative change of fundamental frequency in a sample with a smoothing index of 3 periods, excluding voice breaks. The differences of the quotient amongst all groups were not statistically significant.

Fundamental frequency period change quotient, PPQ (Pitch Perturbation Quotient) describes a relative change of fundamental frequency in a sample with a smoothing index of 5 periods. The statistical analysis did not show significant changes.

Smoothed Pitch Perturbation Quotient (SPPQ), similarly to PPQ, did not appear to be significantly different amongst the groups.

Amplitude modulation index (Shimmer Percent; \%Shim) describes the percentage of relative change in amplitude of a signal in a sample from period to period. We found that the average values in respective groups were not statistically significant.

Relative amplitude modulation index (Shim dB; ShdB) defines short-term changes of peak-to-peak amplitude in a sample. The statistical analysis of logarithm variables did not depict significant changes amongst the groups.

Amplitude Perturbation Quotient (APQ) describes short-term changes of amplitude from period to period with a smoothing index of 11 subsequent periods of laryngeal tone. In our study, we did not find any significant changes amongst the groups.

\section{Smoothed Amplitude Perturbation Quotient; sAPQ)}

Like APQ, the sAPQ parameter describes amplitude peak-to-peak changes with a smoothing index from 1 to 199 periods. The results showed a statistical significance. In children aged $7-12$, a slight decrease of sAPQ was observed in the HL and HA groups, which indicates shortterm stabilization of amplitude control (Table 5).

\begin{tabular}{|c|c|c|c|c|c|}
\hline \multicolumn{7}{|c|}{ Smoothed Amplitude Perturbation Quotient: sAPQ } \\
\hline $\begin{array}{c}\text { Group of patients } \\
\text { with: }\end{array}$ & $\begin{array}{c}\text { No of } \\
\text { patients }\end{array}$ & Average [\%] & $\begin{array}{c}\text { Standard } \\
\text { deviation [\%] }\end{array}$ & Median [\%] \\
\hline Normal hearing & 23 & 7.05 & 2.67 & 5.69 \\
\hline Hearing aids & 20 & 6.07 & 2.86 & 9.03 & Statistical \\
significance & p $<0,02$ \\
\hline Cochlear implants & 20 & 9.59 & 5 & 6.76 & 6.69 \\
\hline $\begin{array}{c}\text { Hearing } \\
\text { impairment }\end{array}$ & 20 & 6.69 & 2.08 & 3.51 & \\
\hline Total: & 83 & 7.34 & & \\
\hline
\end{tabular}

Table 5: Average Value of Smoothed Amplitude Perturbation Quotient (sAPQ)

Peak Amplitude Variation (VAM) defines a relative standard deviation of peak-to-peak amplitude, and short-term peak-to-peak amplitude changes relative to long-term changes. It reveals every voice amplitude change regardless of the cause. In our study, the highest average values of vAm were present in the HL group, and the lowest, in the control group. The differences were statistically significant, with $\mathrm{p}<$ 0.0001 (Table 6).

\begin{tabular}{|c|c|c|c|c|c|}
\hline \multicolumn{7}{|c|}{ Peak Amplitude Variation: $\boldsymbol{v A m}$} \\
\hline $\begin{array}{c}\text { Group of patients } \\
\text { with: }\end{array}$ & $\begin{array}{c}\text { No of } \\
\text { patients }\end{array}$ & Average [\%] & $\begin{array}{c}\text { Standard } \\
\text { deviation [\%] }\end{array}$ & Median [\%] & Geometrical average [\%] \\
\hline Normal hearing & 23 & 14.71 & 4.84 & 14.11 & 14,13 \\
\hline Hearing aids & 20 & 21.02 & 8.78 & 20.42 & 19,58 \\
\hline $\begin{array}{c}\text { Cochlear implants } \\
\text { Hearing } \\
\text { impairment }\end{array}$ & 20 & 22.64 & 10.1 & 20.14 & 20,95 \\
\hline Stalistical \\
significance \\
p
\end{tabular}

Table 6: Average Value of Peak Amplitude variation (vAm)

Hearing impairment causes an increase of vAm leading to voice instability and disturbances in amplitude control. Our study showed a vAm increase in the HL group reaching values almost twice as high as those in the control group. The use of hearing aids and cochlear implants significantly lowered vAm values indicating an improvement of patients auditory control of voice.
This parameter defines an average ratio of non-harmonic energy of the spectrum in a range of $1.5-4.5 \mathrm{kHz}$ to harmonic energy of the spectrum in a range of $70 \mathrm{~Hz}$ to $4.5 \mathrm{kHz}$. Thus, the ratio describes the presence of noise in the analysed signal. In our study, NHR was decreased in the HL and HA groups, whilst a significant increase was noted in the CI group. The results showed a statistical significance (Table 7).

\section{Noise-to-Harmonic Ratio (NHR)}




\begin{tabular}{|c|c|c|c|c|c|}
\hline \multicolumn{5}{|c|}{ Noise to Harmonic Ratio: $N H R$} & \\
\hline $\begin{array}{l}\text { Group of patients } \\
\text { with: }\end{array}$ & $\begin{array}{c}\text { No of } \\
\text { patients }\end{array}$ & Average & $\begin{array}{l}\text { Standard } \\
\text { deviation }\end{array}$ & Median & \multirow{6}{*}{$\begin{array}{c}\text { Statistical significance } \\
\mathrm{p}<0,02\end{array}$} \\
\hline Normal hearing & 23 & 0.17 & 0.06 & 0.15 & \\
\hline Hearing aids & 20 & 0.15 & 0.07 & 0.13 & \\
\hline Cochlear implants & 20 & 0.18 & 0.07 & 0.15 & \\
\hline $\begin{array}{c}\text { Hearing } \\
\text { impairment }\end{array}$ & 20 & 0.14 & 0.05 & 0.13 & \\
\hline Total & 83 & 0.16 & 0.06 & 0.14 & \\
\hline
\end{tabular}

Table 7: Average Value of Noise to Harmonic Ratio (NHR)

\section{Voice Turbulence Index (VTI)}

This index measures a relative level of energy of high-frequency noise. In our study, no statistical significance was found.

\section{Soft Phonation Index (SPI)}

\begin{tabular}{|c|c|c|c|c|c|}
\hline \multicolumn{5}{|c|}{ Soft Phonation Index: SPI } & \multirow{7}{*}{$\begin{array}{c}\text { Statistical } \\
\text { significance } \\
\text { p }<0,005\end{array}$} \\
\hline $\begin{array}{l}\text { Group of patients } \\
\text { with: }\end{array}$ & $\begin{array}{c}\text { No of } \\
\text { patients }\end{array}$ & Average & $\begin{array}{l}\text { Standard } \\
\text { deviation }\end{array}$ & Median & \\
\hline Normal hearing & 23 & 9.43 & 4.22 & 9.54 & \\
\hline Hearing aids & 20 & 7.37 & 7.01 & 5.85 & \\
\hline Cochlear implants & 20 & 4.45 & 2.82 & 3.73 & \\
\hline $\begin{array}{c}\text { Hearing } \\
\text { impairment }\end{array}$ & 20 & 7.59 & 4.54 & 7.1 & \\
\hline Total: & 83 & 7.4 & 5.14 & 6 & \\
\hline
\end{tabular}

This index defines an average ratio of the energy of harmonic components of the low-frequency spectrum $(70 \mathrm{~Hz}$ to $1.6 \mathrm{kHz})$ to harmonic energy of high-frequency components of the spectrum $(1.6 \mathrm{kHz}$ to $4.5 \mathrm{kHz})$.

In our study SPI was lower in the HA and CI groups, however in the CI group the SPI values were higher. The differences between the groups were significant $(\mathrm{p}<0.005)$ (Table 8$)$.

Table 8: Average Value of Soft Phonation Index (SPI)

FO Tremor Intensity Index (FTRI), which analyses frequency tremor, defines the ratio of the frequency of the most intense modulating component to the total frequency magnitude. The values in respective groups presented with a statistical significance (Table 9).

\begin{tabular}{|c|c|c|c|c|c|c|}
\hline \multicolumn{6}{|c|}{ F0 Tremor Intensity Index: FTRI } & \multirow{7}{*}{$\begin{array}{c}\text { Statistical } \\
\text { significance } \\
\mathrm{p}<0,02\end{array}$} \\
\hline $\begin{array}{c}\text { Group of } \\
\text { patients with: }\end{array}$ & No of patients & Average [\%] & $\begin{array}{c}\text { Standard } \\
\text { deviation [\%] }\end{array}$ & Median [\%] & $\begin{array}{c}\text { Geometrical } \\
\text { average } \\
{[\%]}\end{array}$ & \\
\hline Normal hearing & 23 & 0.78 & 0.39 & 0.41 & 0,57 & \\
\hline Hearing aids & 20 & 1.4 & 0.74 & 0.69 & 1,13 & \\
\hline $\begin{array}{l}\text { Cochlear } \\
\text { implants }\end{array}$ & 20 & 1.02 & 0.9 & 0.6 & 1,05 & \\
\hline $\begin{array}{l}\text { Hearing } \\
\text { impairment }\end{array}$ & 20 & 1.81 & 1.37 & 1.4 & 1,98 & \\
\hline Total: & 83 & 1.27 & 0.62 & 0.61 & 1,04 & \\
\hline
\end{tabular}

Table 9: Average Value of F0 Tremor Intensity Index

The increase of the index, which almost double compared with the control group, was noted in the HL group.

In the HA and CI groups, we observed a significant decrease in FTRI, whilst in the CI group the decrease was greater. This was reflected in an observed decrease of voice tremor in the patients.

Amplitude Tremor Frequency Index (ATRI) expresses an average ratio of amplitude of modulation components in the signal $(30 \mathrm{~Hz}$ to $400 \mathrm{~Hz}$ ) to its averaged maximum amplitude. This parameter serves as a measure of discrete tremor of laryngeal tone. In our study, ATRI did not present with a statistical significance.

Degree of Voice Breaks (DVB) describes voice breaks, (i.e.: the ratio of the total length of breaks to the total length of the sample). In our study, the ratio did not present statistically significant changes amongst the groups for frequency of occurrence of positive DVB values. Statistically insignificant, were also the differences in frequency of the occurrence of voice breaks. 
Degree of Sub-Harmonics (DSH) defines the ratio of the number of subharmonic tones to the number of periods of basic tone in all segments of the sample. For a healthy voice, the value of DSH should be equal to zero. In voice disturbances, DSH reaches positive values, which means that higher harmonic components of laryngeal tone appear, and they overlap the fundamental frequency. Our study did not reveal statistically significant changes amongst the groups.

Degree of Voiceless (DUV) describes the number of subharmonic segments (where F0 is not present) in the total sample. In a healthy voice, the value of DUV should be equal to zero. We did not observe significant changes amongst the groups.

\section{Discussion}

Some reports in the literature describe changes in acoustic voice parameters in people with hearing impairment. Auditory-voice feedback, controlled by the central nervous system, is inaccurate due to hearing loss, and results in a poor control of voice [1-3]. Other researchers have described the influence of various factors that cause disturbances in voice parameters. These factors include the onset of the hearing impairment, the length of time between onset and audiological intervention, and the type of rehabilitation. We can conclude from the literature that hearing impairment most commonly causes changes in frequency parameters (F0, vF0, jitter, \%jitter), presence of noise components (NHR, SPI), and voice tremor (ATRI, FTRI). The changes occur as a result of incoordination between laryngeal muscles and disfunction of respiratory tract aerodynamics [6-11].

One of the most significant parameters in describing voice conditions is fundamental frequency (F0). According to various authors, the average fundamental frequency in children is $250-275 \mathrm{~Hz}$. However, because this changes as a function of a child's growth, its analysis requires reference to studies reflecting its developmental variability [12-13]. Giusti, et al. performed a study to examine the influence of deafness on patients voices. They examined 64 patients with prelingual deafness, aged 6-13 years [14]. They observed a significant increase of fundamental frequency (average value $435 \mathrm{~Hz}$ ) and the deterioration of voice quality as assessed perceptually in $90 \%$ of patients. Significant variability of fundamental frequency was also noted, approximating 13 semitones. The voice was described as tense, strained, less melodic, and guttural. These observations were confirmed by the studies of Das, et al., who observed irregular cramps of the glottis resulting in a lack of control of vocal fold tension and subglottic pressure, negatively affecting voice quality [15].

According to some researchers, disturbed tension of internal laryngeal muscles underline an increased fundamental frequency F0 and its variability (vF0) as well as the disturbances of other acoustic voice parameters. Pruszewicz, et al. observed the highest variability of fundamental frequency from cycle to cycle and the greatest lack of control for amplitude and frequency in children with congenital deafness [16]. Szkiełkowska, et al. examined the values of fundamental frequency in a group of 165 children, aged 2 months to 12 years, divided into four subgroups according to age. In all subgroups of deaf children, excluding the youngest, 212 months, a significantly higher fundamental frequency F0 was observed when compared with the control group. The most noticeable differences occurred in children aged 1-3 years and 7-12 years [17]. The researchers observed the most crucial changes of fundamental frequency in deaf children compared with the control group in the age range of 1-3 years. After this age, as both hearing and hearing-impaired children grow, average values of F0 decrease gradually. In our study, in the HL subgroup of hearing-impaired children, the highest average fundamental frequency was observed $(289.49 \mathrm{~Hz})$. The study conducted six months after hearing aids had been fitted (HA group) showed that the average fundamental frequency was slightly lower, whilst a significant decrease was noted in children with cochlear implants (CI group). Similar observations were made by Delgado-Pinheiro, et al. [18], who compared acoustic voice parameters in hearing-impaired children, aged 3-18 years, to their normally hearing peers. The results showed a gradual decrease of the average fundamental frequency, similar to other researchers observations. The research of Delgado-Pinheiro, et al. revealed statistically significant differences in hearing-impaired people versus the control group for vFO (variability of fundamental frequency) and vAm (variability of amplitude). The average values of both parameters were lower in hearing-impaired children. This indicates voice instability, which was also reflected in a voice perception assessment. In profoundly hearing-impaired people, greater voice irregularity and nasalence were present.

The results of our study also illustrate significant differences in $\mathrm{vFo}$ and vAm values in hearing-impaired children compared with their normally hearing peers. The values of these parameters were significantly higher in hearing-impaired children compared with the control group. The decrease of F0 as a function of age can be explained by growth, longer length of time of exposure to sounds, and anatomical differences in the structure of the larynx and vocal tract. Audiological intervention, either with the use of a hearing aid or cochlear implant, plays a crucial role in the normalization of the above parameters [19-28]. The results of our study show a convergence with other researchers` studies performed with other age groups. The studies show a general agreement that a cochlear implant, as a modern auditory prosthesis, is a much more effective tool, than a traditional hearing aid, to improve the acoustic control of voice in hearingimpaired children.

\section{Conclusions}

A long-term hearing deprivation, regardless of the level of hearing impairment, disturbs the acoustic structure of voice in children. As our research shows, the most significant changes include fundamental frequency (F0), highest fundamental frequency (Fhi), variability of fundamental frequency ( $\mathrm{vF} 0)$, number of periods of fundamental frequency (PER), amplitude perturbation quotient (sAPQ), variability of amplitude (vAm), noise to harmonic ratio (NHR), soft phonation index (SPI), and frequency tremor index (FTRI). As a result, patients with a profound level of hearing impairment develop long-term problems in the control of voice frequency and amplitude. Acoustic analysis confirmed that the use of hearing rehabilitative devices significantly improves the majority of acoustic voice parameters. The improvement of acoustic voice parameters reflects improved auditory control of voice frequency and amplitude, and a decrease in noise components and voice tremor. Significantly better voice results we observed in children who have cochlear implants.

\section{References}

1. Kumar V, Croxson P, Simonyan K. (2016). Structural organization of the laryngeal motor cortical network and its implication for evolution of speech production. J Neurosci; 36 (15): 4170-4181.

2. Schulz G, Varga M, Jeffires K, Ludlow C, Braun A. (2005). Functional neuroanatomy of human vocalization. Cereb Cortex; 15 (12): 1835-1847.

3. Simonyan K, Ackerman H, Chang EF, Greenlee JD. (2016). New developments in understanding the complexity of human speech production. J Neurosci; 36 (45): 11440-11448.

4. Coelho AC, Brasolotto AG, Bevilaqua MC, Mortari Moret AL., Bahmad Junior F. (2016). Hearing performance and voice acoustics of cochlear implanted children. Braz J Otorhinolaryngol; 82(1):70-75

5. Skrypnik I, Grzanka A, Puuronen S, Szkiełkowska A. (2001). Selection of Voice Features to Diagnose Hearing Impairments of Children. IEEE CS Press; 427-432. 
6. Campisi P, Low A, Papsin B, Mount R, Harrison R. (2006). Multidimensional Voice Program Analysis in Profundly Deaf Children: Quantifying Frequency and Amplitude Control. Perceptual and Motor Skills; 103, 40-50.

7. Souza LBR, Bevilacqua MC, Brasolotto AG, Coelho AC. (2012). Cochlear implanted children present vocal parameters within normal standards. Int J Pediatr Otorhinolaryngol.04.029. PMid:22652499

8. Campisi P, Low A, Papsin B, Mount R, Cohen-Kerem R, Harrison R. (2005). Acoustic analysis of the voice in pediatric cochlear implant recipients: a longitudinal study. The Laryngoscope; 115(6): 1046-1050

9. Evans MK, Deliyski DD. (2007). Acoustic voice analysis of prelingually deaf adults before and after cochlear implantation. $J$ Voice; 21(6): 669-682

10. Myszel K. Szkiełkowska A. (2020). Development of voice in hearing-impaired individuals: overview of physiopathological aspects. J Hear Sci; 10(3):19-23.

11. Zhang Z. (2016). Mechanics of human voice production. J Acoust Soc Am; 140(4): 2614-2635

12. Markova D, Richer L, Pangelinan M, Schwartz DH, Leonard G, et.al (2016). Age- and sex-related variations in vocal-tract morphology and voice acoustics during adolescence. Horm Behav; 81:84-96.

13. Kent RD, Eichhorn JT, Vorperian HK. (2021). Acoustic parameters of voice in typically developing children ages 4-19 years. Int J Pediatr Otorhinolaryngol;142:110614

14. Giusti Maria C, Padovani M, Behlau M, Granato L. (2001). The voice of hearing impaired children. ENT. Brazilian Society Official Publication

15. Das B, Chatterjee I, Kumar S. (2013). Laryngeal aerodynamics in children with hearing impairment versus age and height match normal hearing peers. Otolaryngology. Article 394604.

16. Pruszewicz A, Demenko G, Wika T. (1993). Variability analysis of Fo parameter in the voice of individuals with hearing distrurbances. Acta Otolaryngol; 113 (3): 450-454

17. Szkiełkowska A., Ratyńska J., Markowska R. (2002). Zmiany częstotliwości podstawowej głosu dzieci niesłyszących w zależności od wieku. Audiofonologia ;XXII:149-154.

18. Delgado-Pinheiro E.M, Bonbonati J.C, Rodrigues dos Santos F, Gradim Fabron E.M. (2020). Voice of hearing impaired children and adolescents and hearing peers: influence of speech auditory perception on vocal production. CoDAS; 32 (4):e20180227.

19. Upadhyay M, Datta R, Nilakantan A, Goyal S, Gupta A, et.al (2019). Voice Quality in Cochlear Implant Recipients: An Observational Cross Sectional Study. Indian J Otolaryngol Head Neck Surg;71(Suppl 2):1626-1632.

20. Szkiełkowska A., Skarżyński H., Piotrowska A., Lorens A., Szuchnik J. (2008). Kompleksowe postępowanie u dzieci po wszczepach implantów ślimakowych. Otorynolaryngologiaprzeglad kliniczny;VII:77-84.

21. Hocevar-Boltezar I, Vatovec J, Gros A, Zargi M. (2005). The influence of cochlear implantation on some voice parameters. Int J Pediatr Otorhinolaryngol,; 69(12): 1635-1640

22. Nunez-Batalla F, Vasile G, Carton-Corona N, (2019). Vowel production in hearing impaired children: A comparison between normal-hearing, hearing-aided and cochlear implanted children. Acta Otorrinolaringol Esp.; 70:251-257.

23. Saki N, Bayat A, Nikakhlagh S, Zamani P, Khaleghi. (2020) Acoustic Voice Analysis in Postlingual Deaf Adult Cochlear Implant Users: A Within-Group Comparison Study. J Voice. Jul 7:S0892 1997(20)302265

24. Joy JV, Deshpande S, Vaid DN. (2017). Period for Normalization of Voice Acoustic Parameters in Indian Pediatric Cochlear Implantees. J Voice. 2017 May;31(3):391.e19-391.e25

25. Wang Y, Liang F, Yang J, Zhang X, Liu J, Zheng Y.The Acoustic Characteristics of the Voice in Cochlear-Implanted Children: A Longitudinal Study. J Voice. 2017 Nov;31(6):773.e21-773.e26.

26. Jafari N, Izadi F, Salehi A. (2017). Objective Voice Analysis of Pediatric Cochlear Implant Recipients and Comparison with Hearing Aids Users and Hearing Controls. J Voice. Jul;31(4):505.e11-505.e18.

27. Gautam A, Naples JG, Eliades SJ. (2019) Control of speech and voice in cochlear implant patients. Laryngoscope. 129(9):2158-2163.

28. Ubrig MT, Tsuji RK, Weber R, Menezes MHM, Barrichelo VMO, da Cunha MGB, Tsuji DH, (2019) Goffi-Gomez MVS The Influence of Auditory Feedback and Vocal Rehabilitation on Prelingual Hearing-Impaired Individuals Post Cochlear Implant. J Voice. 33(6):947.e1-947.e9.

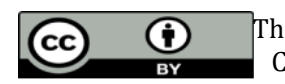

This work is licensed under Creative Commons Attribution 4.0 License
Ready to submit your research? Choose Auctores and benefit from:

* fast, convenient online submission

* rigorous peer review by experienced research in your field

* rapid publication on acceptance

* authors retain copyrights

* unique DOI for all articles

* immediate, unrestricted online access

At Auctores, research is always in progress.

Learn more www.auctoresonline.org/journals/journal-of-clinicalotorhinolaryngology 